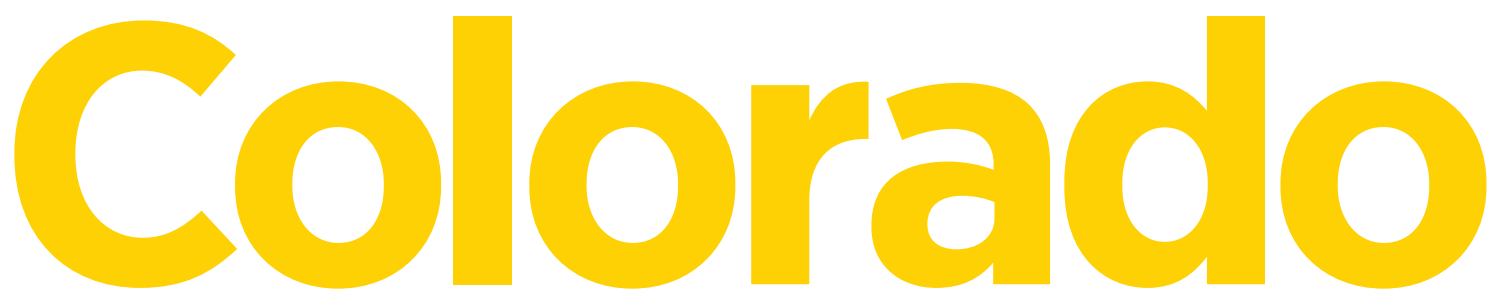

The U.S. Department of Energy (DOE) is pursuing an all-ofthe-above approach to developing every source of American energy. The Office of Energy Efficiency and Renewable Energy (EERE) leads DOE efforts to build a strong clean energy economy, a strategy that is aimed at reducing our reliance on foreign oil, saving families and businesses money, creating middle-class jobs, and reducing pollution.

This strategy will position the United States as the global leader in clean energy, increasing our nation's competitiveness. In 2012, \$268 billion was invested globally in clean energy, a $500 \%$ increase since $2004 .{ }^{8}$ Trillions of dollars will be invested in the coming decades. Clean energy represents one of the most important economic development races of the 21 st century. We face a stark choice - the clean energy technologies of tomorrow can be invented and manufactured in Colorado and the rest of the United States for domestic use and export around the world, or we can cede global leadership and import those technologies from China, India, Germany, and elsewhere.

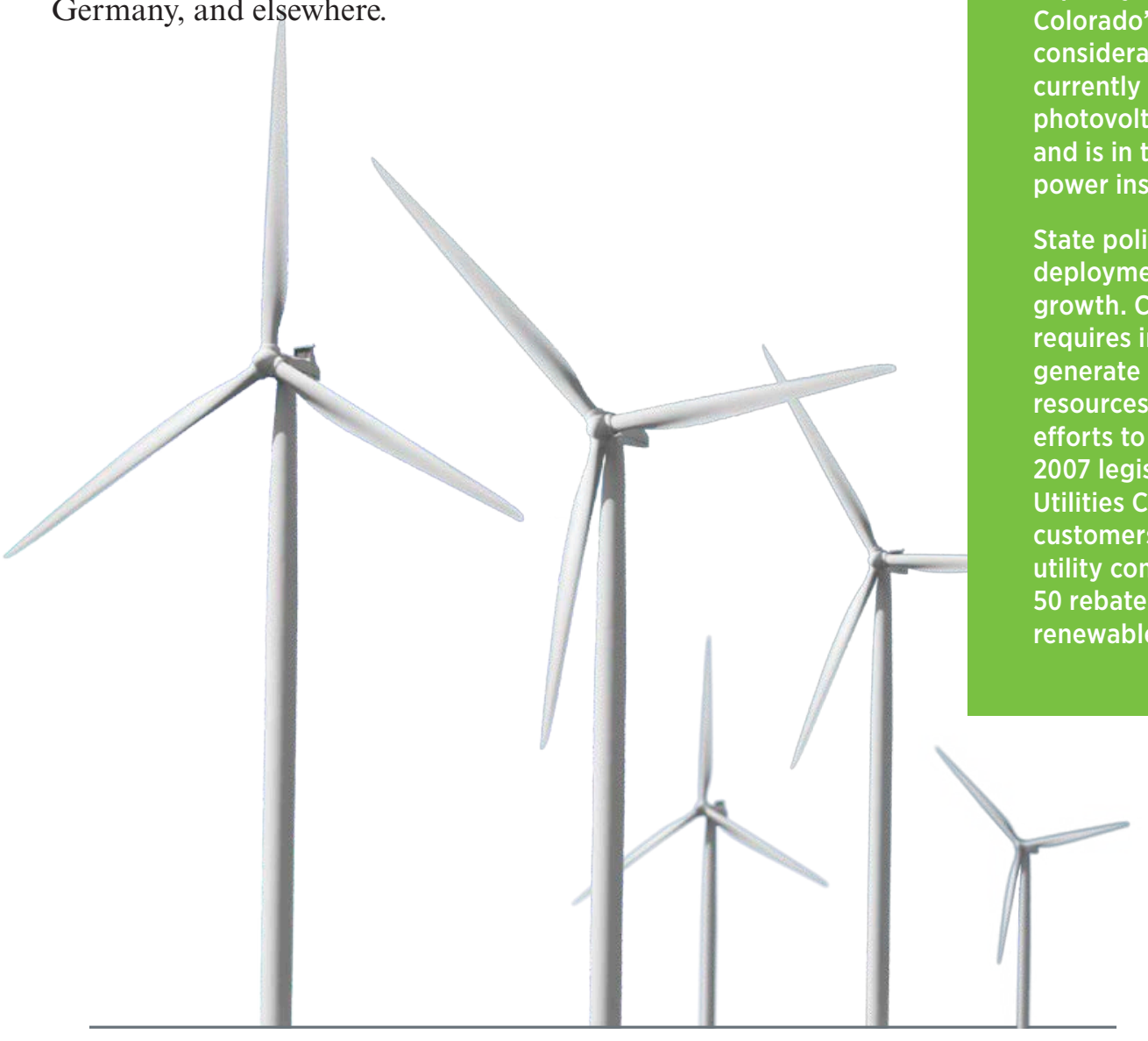

\section{Colorado's Clean Energy Resources and Economy}

- Clean Economy Jobs (2010): 51,036+

- Average Annual Growth Rate of Clean Economy Jobs (2003-2010): 5.6\%

- Average Annual Wage of Clean Economy Jobs (\$2009): \$45,973

With its abundant renewable energy resources and continued focus on supporting renewable energy deployment, Colorado has emerged as a leader in clean energy. Currently, $14 \%$ of Colorado's generated electricity comes from renewable resources. ${ }^{2}$ Colorado's high Rocky Mountain ridges offer considerable wind power potential, some of which has been tapped to supply nearly $10 \%$ of Colorado's in-state electricity generation. ${ }^{3}$ Colorado's 1,800 megawatts of installed wind capacity ranks the state ninth in the nation. ${ }^{4}$ Colorado's use of solar is also impressive, with considerable growth in recent years: Colorado ranks third in the nation in installed solar and is in the top five states for concentrated solar installed nameplate capacity.

State policies supporting renewable energy deployment have positively contributed to this growth. Colorado's Renewable Energy Standard requires investor-owned electric utilities to generate $30 \%$ of their power from renewable energy resources by $2020 .{ }^{6}$ Colorado also strongly supports fforts to reduce energy waste; in response to a 07 legislative mandate, the Colorado's Public Utilities Commission directed utilities to help their customers reduce electricity use, and Colorado utility companies currently sponsor approximately 50 rebate programs for energy efficiency and renewable energy. ${ }^{7}$
U.s.oparertent of

Energy Efficiency \& Renewable Energy 


\section{EERE and Colorado}

EERE helps create Colorado's clean energy economy today, developing and delivering innovative, market-driven solutions for the following:

- Sustainable transportation - making transportation cleaner and more efficient through solutions that put electric drive vehicles on the road and replace oil with clean domestic fuels

- Renewable electricity generation - reducing the cost of renewable energy through solutions that squeeze more usable power from sustainable resources and improve the economics of manufacturing and installation

\section{- Energy-saving homes, buildings, and manufacturing -} developing cost-effective energy-saving solutions that help make our country run better through increased efficiency_promoting better plants, manufacturing processes, and products; more efficient new homes and improved older homes; and other solutions to enhance the buildings in which we work, shop, and lead our everyday lives.

\section{EERE Investments in Colorado}

EERE invests in Colorado through a broad range of clean energy projects, from energy efficiency to solar, wind, water, biofuels, vehicles, and other technologies. Working with public and private partners in Colorado, EERE supports cities, communities, and families in developing innovative, costeffective energy solutions through research, demonstration, and deployment activities with Colorado businesses, universities, nonprofits, and local governments. EERE works closely with DOE's National Renewable Energy Laboratory (NREL) in Golden, Colorado - as EERE's and DOE's primary national laboratory for renewable energy and energy efficiency research, development, demonstration, and related activities that advance technologies from concept to the commercial marketplace. Many of NREL's discoveries in renewable energy that EERE has funded have led the way in providing multiple viable renewable options to power our homes and businesses, and have shaped our transportation alternatives.

\section{Sustainable Transportation}

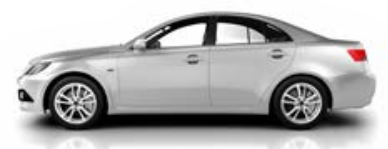

\section{Colorado-Based Plant Advances Electric Drive Systems}

Longmont, $\mathrm{CO}$

EERE investment: $\$ 48 \mathrm{M}$

Partnering with UQM Technologies, EERE supported the purchase and renovation of the company's new 130,000-square-foot Longmont electric drive component plant through the American Recovery and Reinvestment Act (ARRA), and provided an additional $\$ 3$ million for costshared research and development $(\mathrm{R} \& \mathrm{D})^{9}$ to promote more efficient and cost effective electric vehicle technologies. The company is doing so by working to develop non-rare-earth magnet electric motors. UQM matched both the ARRA and $\mathrm{R} \& \mathrm{D}$ funds dollar for dollar, investing $\$ 48$ million in the project, and is currently providing Electric Vehicles International with electric propulsion systems to install in UPS delivery vans. When the company completes its bus and truck production system at the plant, it will have the capacity to produce at least 20,000 electric drive systems a year for electric drive vehicles, which use less oil and produce fewer greenhouse gases compared to conventional vans.

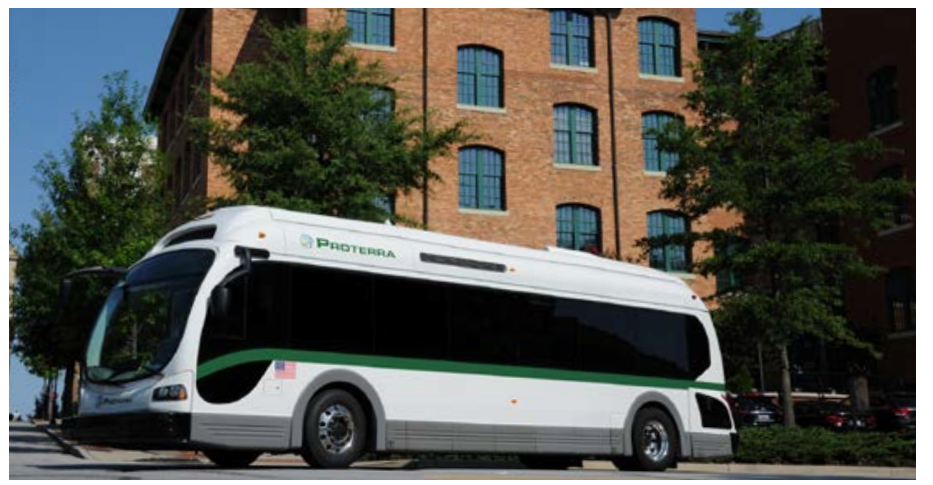

The Proterra EcoRide ${ }^{T M}$, an electric bus soon to be deployed in several cities throughout the country, includes components manufactured by Colorado's UQM Technologies. UQM's plant will have the capacity to produce 20,000 electric drive systems a year for electric drive vehicles. Photo from Proterra, Inc.

\section{University of Colorado-Boulder Researches Solar-Thermochemical Hydrogen Production}

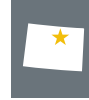

Boulder, Colorado

EERE investment: $\$ 1.5 \mathrm{M}$

EERE funds research at the University of Colorado-Boulder for a hydrogen production technology that uses solar energy to produce hydrogen from water. The thermochemical process being used has minimal water requirements, in contrast to conventional central power plants using nuclear reactors or coal-fired boilers, which typically need to be sited near a significant source of water. In addition, the process does not produce waste water, ash, waste heat, or greenhouse emissions as conventional power stations do, so no waste water treatment, gas capture and sequestration, or other remediation is needed. Because the process employs two-step, non-volatile, metal-oxide cycles, it avoids efficiency losses that are associated with product recombination and temperature quenching, or in an electrolysis step. The conversion of solar radiation into chemical fuel, such as hydrogen, is an engineering challenge; however, unlike solar-derived electricity or heat, hydrogen can be stored and transported easily and efficiently, making it suitable for vehicles and other portable applications. 
University Trains Next Generation of Engineers, Technicians, and First Responders

\section{Boulder, Colorado}

EERE investment: $\$ 2.5 \mathrm{M}$

Partnering with EERE, Colorado State University (CSU) is carrying out the Advanced Electric Drive Vehicle Education Program, which trains secondary school and community college teachers to integrate information on electric drive vehicles into their curricula. Program alumni have already found positions in the automotive industry. CSU is also developing a number of college courses for undergraduates, including advanced training for automotive technicians, and training for police and firefighters who may have to respond to incidents involving electric drive vehicles. CSU and its partners have invested nearly $\$ 1$ million in the program.

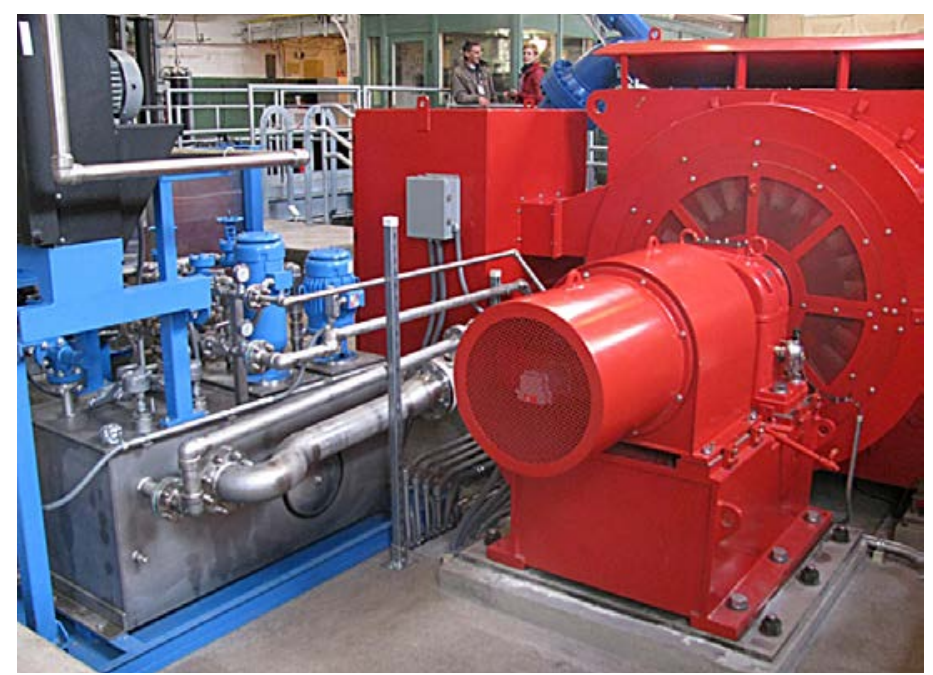

The Boulder Canyon Hydroelectric Facility's new, highly-efficient turbine. Photo from the City of Boulder in Boulder, Colorado

\section{Clean Cities Coalitions Help Stakeholders Choose Smart Transportation Solutions}

Denver, Northern Colorado, Southern Colorado EERE investment: $\$ 30 \mathrm{~K}$ annually to each coalition

EERE coordinates a network of nearly 100 Clean Cities coalitions - self-organized groups of local community, government, and business stakeholders whose efforts to adopt smart transportation solutions have displaced more than 4.5 billion gallons of gasoline and diesel since 1993 . Colorado is home to three Clean Cities coalitions: Denver Clean Cities, Northern Colorado Clean Cities and Southern Colorado Clean Cities. In 2011, these three coalitions reduced fuel consumption by the equivalent of nearly 5 million U.S. gallons of gasoline and prevented nearly 25,000 tons of greenhouse gas emissions. Together, the coalitions include more than 200 businesses, local governments, and other organizations, and work to promote the use of the more than 400 alternative fuel and charging stations in Colorado. In 2011, the three coalitions leveraged DOE's support to raise more than $\$ 1$ million from businesses, local governments, other organizations, and non-DOE grants.

\section{Renewable Electricity Generation}

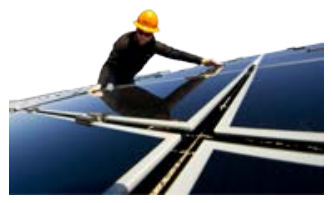

\section{Streamlining Processes Across Local Governments Makes Solar More Affordable}

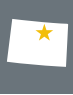

\author{
Boulder, Colorado \\ EERE investment: \$490K
}

\section{EERE supports the Colorado Solar Energy Industries}

Association (COSEIA) partnership with Denver, Fort Collins, Golden, Boulder County, and the Rocky Mountain Institute to help local governments reduce the soft costs of installation, including permitting, interconnection and inspection, by streamlining processes. COSIEA has developed and released 12 best practices documents that guide local governments through the complex processes of permitting and inspection-processes that can vary dramatically across Colorado's more than 200 cities and towns, 64 counties, and 65 utilities.

City of Boulder Modernizes Boulder Canyon Hydroelectric Project to Improve Generation Efficiencies

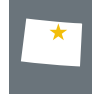

$$
\begin{aligned}
& \text { Boulder, Colorado } \\
& \text { EERE investment: } \$ 1.18 \mathrm{M}
\end{aligned}
$$

Partnering with EERE, the City of Boulder modernized the Boulder Canyon Hydroelectric facility, which began in January 2010 and was completed in October 2012. Constructed in 1910, the existing hydropower turbines and generators were nearing the end of their useful lives. With EERE funding, Boulder has installed a single new turbine and generator unit that is appropriately sized for the available water flow. This unit is expected to increase generation by as much as $30 \%$ and turbine efficiency by $18 \%$ to $48 \%$. Throughout its 50-year expected lifespan, the new, more efficient turbine and generator unit is expected to generate approximately 500,000 megawatt hours of additional electricity, which is enough to power more than 43,000 homes for a year. ${ }^{10}$ The project has created or preserved seven full-time jobs. In addition to saving energy, this project leverages millions of dollars from local sources. ${ }^{11}$ 


\section{Working with the National Renewable Energy Laboratory}

\author{
Golden, Colorado
}

For 35 years, NREL has worked with EERE to deliver knowledge and innovations that have pushed the boundaries of what is possible, helping to enable the emergence of a national clean energy industry. Below are just a few examples of EERE projects with NREL.

\section{Device Allows for Real-Time, Detailed Chemical Analysis to Better Understand Fuel Yields from Biomass}

\section{EERE investment: \$3M}

Utilizing EERE funds, NREL installed and customized the transportable molecular beam mass spectrometer (MBMS), which is a scientific measuring device that allows real-time, detailed chemical analyses of gaseous products. For example, it is the only instrument in the world that enables direct analysis of hot syngas (whose production is an intermediate step in biomass to biofuel conversion) without needing to significant pre-condition biomass. In contrast, most analytical techniques require cooling, cleaning, or other preprocessing steps, which limit the understanding of syngas composition analysis. Data obtained using the MBMS at NREL can eventually help make improvements to thermochemical and catalytic systems to increase the overall yield of fuel from biomass. Discoveries like this will bolster the commercialization potential of such technologies by driving down the projected production costs of "drop-in" hydrocarbon biofuels (gasoline, diesel, and jet fuel blendstocks) made from renewable, lignocellulosic biomass.

\section{NREL Research Contributes to Improvements in Enzymatic Hydrolysis and Fermentation Yields to Pretreat Biomass Materials}

\section{EERE investment: \$3M}

NREL, through EERE-funded research, recently implemented a cost-effective strategy for pretreatment - treating biomass materials prior to processing that can reduce cellulosic ethanol production costs. While great strides have been made in improving performance and reducing costs associated with both enzymes and fermentation organisms, most of these biological entities are still inhibited by acetic acid.
This new, relatively inexpensive approach to pretreatment reduces levels of acetic acid early in the process, which should drive down ethanol production costs through improved yields of sugar and ethanol from biomass materials.

\section{NREL to Open New Test Facility}

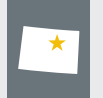

$$
\begin{aligned}
& \text { Louisville, Colorado } \\
& \text { EERE investment: } \$ 10 \mathrm{M}
\end{aligned}
$$

Utilizing EERE American Recovery and Reinvestment Act of 2009 funding, NREL's National Wind Technology Center (NWTC) will be opening a new dynamometer test facility fall 2013. Dynamometers enable industry and testing agencies to verify the performance and reliability of both wind turbine drivetrain prototypes and commercial machines before they are deployed in the field, thus reducing the risk of possible failures and maintenance or replacement costs. The new facility will be used to conduct research aimed at accelerating the development and deployment of next-generation wind energy technologies for both offshore and land-based applications. As one of the largest dynamometers in the world and using equipment that simulates all forces and movements turbine components exert on each other, NWTC's new facility will be capable of testing the performance of wind turbine drivetrains with capacity ratings up to 5 megawatts and doing so with a level of detail fidelity found in only a handful of facilities worldwide.

\section{General Electric to Commercialize NREL-Developed High-Efficiency Solar Cell}

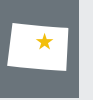

\section{Golden, Colorado \\ EERE investment: $\$ 3.9 \mathrm{M}$}

General Electric (GE) will manufacture an NRELdeveloped thin-film photovoltaic cell and plans to build a large-scale solar module plant in Colorado. The new cell, which employs a thin layer of cadmium telluride on glass, will enable more efficient, less expensive manufacturing of high-performance solar panels. This technology was originally commercialized by PrimeStar Solar, which GE acquired in 2011. This collaboration between NREL and the private sector will promote the cost-effective production of clean solar power technology on a large scale. 


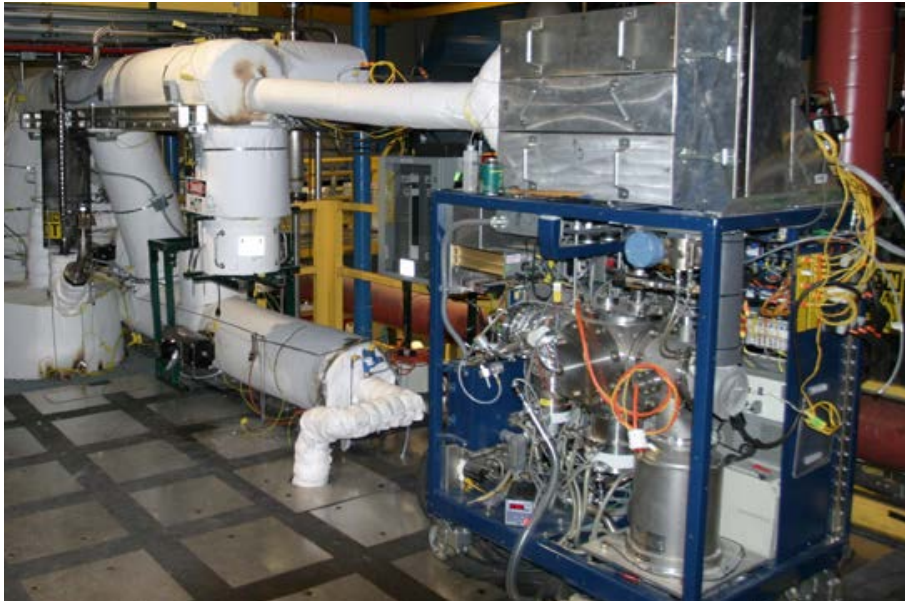

NREL installed a Molecular Beam Mass Spectrometer-a scientific measuring device that allows real-time, detailed analysis of gaseous vapors. Photo by Calvin Feik, NREL 16021

\section{Colorado Firm Develops Innovative Materials for Geothermal Systems}

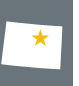

\author{
Lafayette, Colorado \\ EERE investment: $\$ 3.3 \mathrm{M}$
}

With support from EERE, Composite Technology

Development, Inc. is advancing several technologies related to geothermal energy extraction. The company is developing materials designed to create and conserve geothermal reservoirs in harsh downhole environments to produce energy. Composite uses an innovative polymer material to enhance the reservoir, preventing leakage and targeting fluid contact with the hottest zones in the subsurface. Contact with the hot rock heats the fluid to sufficient temperatures for geothermal energy production. Composite is also developing electronic systems that can sustain higher temperatures and pressures than existing systems - enabling well monitoring of enhanced geothermal systems, among other applications. Finally, the company plans to commercially produce a high-performance, composite-based wire insulation material, originally developed by DOE laboratories, for mechanical durability in extreme conditions.

\section{Phillips County Installs Community Wind Power}

Haxtun, Colorado EERE investment: $\$ 2.5 \mathrm{M}$

Supported by an investment from EERE, Phillips County is building a community-owned wind project. This 20-turbine installation, which will connect to the area's existing transmission grid, will generate enough renewable electricity to power about 9,000 homes. It will also generate income in the county through local tax revenue, landowner lease income, community ownership profits, and job creation.

\section{Developing Tomorrow's Wind Turbine Designs}

\author{
Boulder, Colorado \\ EERE investment: $\$ 486 \mathrm{~K}$
}

Boulder Wind Power developed a concept design for a 6-megawatt offshore wind turbine drivetrain by using its patented technology — an innovative, permanent-magnet, direct-drive generator. Supported by an EERE investment, the company demonstrated a 3-megawatt-scaled version of the generator design for system-level testing. The company also used conceptual designs through 10 megawatts to demonstrate how the drivetrain could, at higher power ratings, drive toward a levelized energy cost of less than $\$ 0.10$ per kilowatt hour in offshore wind applications. The project team tested several components to ensure that the design met performance and safety standards. At the end of the preliminary design phase, Boulder Wind Power secured business partnerships with two major original equipment manufacturers of wind turbines to further the development and demonstration of the design.

\section{Energy-Saving Homes, Buildings, and Manufacturing}

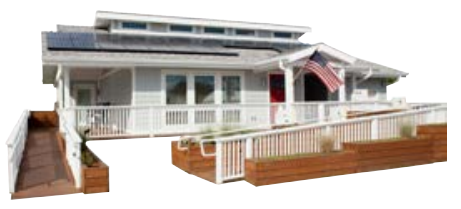

\section{Colorado State University Industrial Assessment Center Saves Manufacturers Money and Trains the Next Generation of Engineers}

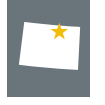

Fort Collins EERE investment: $\$ 1.3 \mathrm{M}$

Partnering with EERE, Colorado State University's Industrial Assessment Center (IAC) provides small- and medium-sized manufacturing companies with no-cost energy assessments, while also serving as an important training ground for the next generation of energy-savvy engineers. Through IAC assistance, manufacturers have saved Colorado companies more than $\$ 19$ million in energy costs by performing more than 650 assessments to date, for an average of $\$ 30,500$ in energy cost savings per assessment. Nationally, these assessments have helped participating manufacturers save more than $\$ 5.6$ billion in energy costs. 


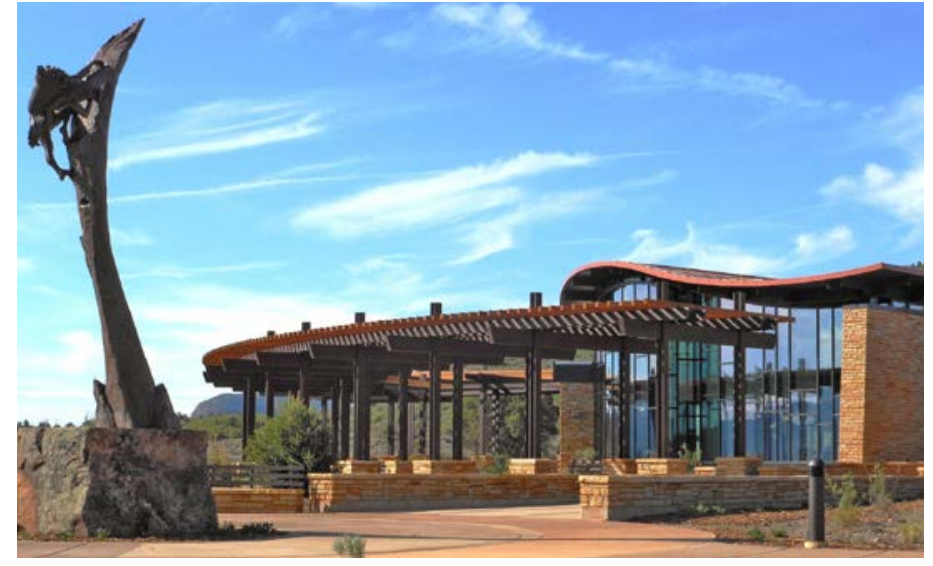

The new Mesa Verde Visitor and Research Center opened in December of 2012. This view is of the welcome plaza at the entrance to the facility. Photo from the National Park Service

\section{Mesa Verde's New Museum Is a Showcase for Sustainable Building Technologies}

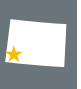

Cortez, Colorado

EERE investment: \$15K

Mesa Verde National Park's visitor center blends state-ofthe-art energy technology with traditional Native American building principles to create a high-performance, Leadership in Energy and Environmental Design Platinum-certified sustainability showcase. The center consumes about $28 \%$ less energy than comparable commercial buildings, and through solar panels and solar water heaters, it generates $95 \%$ of its required energy. Passive solar design (using the sun's energy for heating and cooling), like that employed by Mesa Verde's indigenous dwellers centuries ago, also contributes to energy savings. EERE technical assistance enabled this project to proceed with cooperation from the General Services Administration and the National Park Service.

\section{EERE-Supported Appliance Rebate Program in Colorado}

\section{State of Colorado}

EERE investment: $\$ 4.7 \mathrm{M}$

In 2010, the State of Colorado implemented a residential appliance rebate program with ARRA funding from EERE. Colorado residents quickly obtained $\$ 75-\$ 500$ rebates to purchase ENERGY STAR ${ }^{\circledR}$ qualified boilers, clothes washers, dishwashers, furnaces, refrigerators, and water heaters. In partnership with Recharge Colorado, the program launched a marketing campaign to promote energy efficiency and renewable energy opportunities to consumers across the state. More than 38,000 rebates have been provided for covered appliances - totaling $\$ 5.8$ million. ${ }^{12}$

\section{Better Buildings Neighborhood Program Drives Energy Efficient Improvements in Colorado}

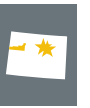

\author{
Boulder County, Colorado; Denver County, \\ Colorado; and Garfield County, Colorado
}

EERE's Better Buildings Neighborhood Program, part of the EERE Better Buildings Initiative, is working to spur Colorado homeowners and businesses into energy-saving action. Since January 2011, the Better Buildings communities of Boulder, Denver, and Garfield Counties have paired homeowners with an Energy Advisor - an expert who helps buildings move from assessment to upgrade with minimal hassle. Combining financing incentives with step-by-step assistance from the Energy Advisor, the program has effectively addressed many key barriers in the energy upgrade process, resulting in more energy improvements and happy customers.

\section{Better Building Partnerships Help America's Commercial and Industrial Buildings Become at Least 20\% More Efficient over the Next Decade}

The United States spends about \$200 billion each year just to power commercial buildings and another approximately $\$ 200$ billion to power manufacturing facilities. The Better Buildings Challenge was launched to help America's commercial and industrial buildings become at least $20 \%$ more efficient over the next decade. To achieve this aggressive target, EERE is working with leading public and private-sector partners to implement energy-saving practices that reduce energy waste, save money, and create jobs. ${ }^{13}$ Colorado is home to many projects that showcase the work of these leading organizations and provide successful models and best practices, which can be replicated across the country to help drive dramatic advancements in energy efficiency.

\section{Colorado EnergySmart Program}

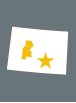

Eagle County, Colorado; Pitkin County, Colorado; and Gunnison County, Colorado

Eagle, Pitkin, and Gunnison Counties launched Energy Smart in January 2011 to reach a diverse population of vacationers, second homeowners, and seasonal workers with an energyefficiency program. The program is a "one-stop-shop" to simplify access to information and financing, as well as ensure a skilled workforce to make energy-efficiency upgrades in a variety of housing types. EnergySmart worked with Colorado Mountain College to provide Building Performance Institute training, offering individuals $\$ 1,000$ toward this training. EnergySmart also loaned energy-efficiency testing tools to contractors to reduce initial investment costs. ${ }^{14}$ 


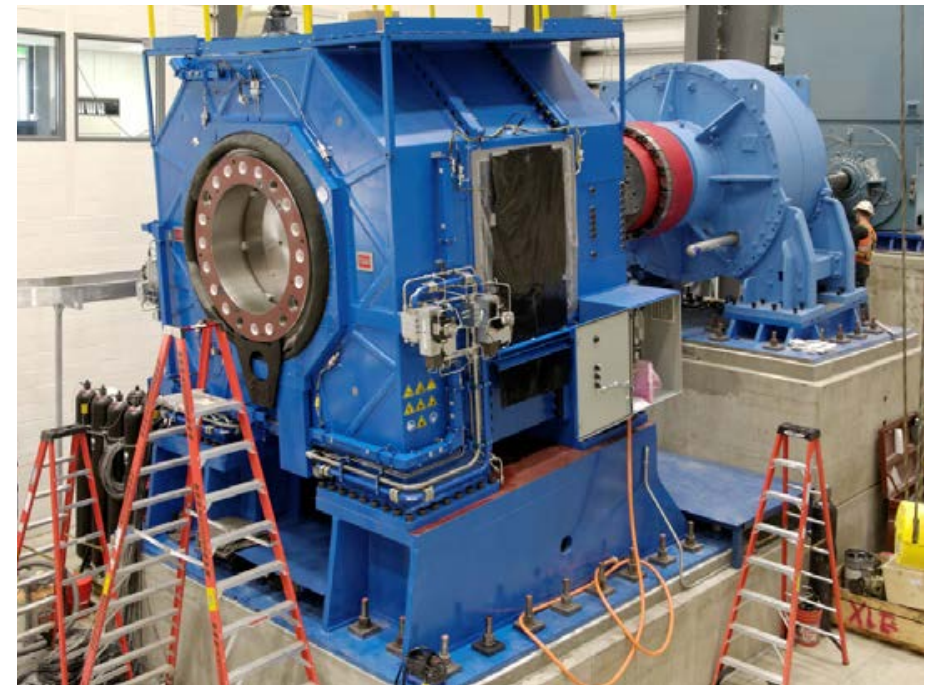

NREL's National Wind Technology Center will house one of the largest dynamometers in the world, which will help accelerate wind technology development by enabling testing of the performance and reliability of both wind turbine drivetrain prototypes and commercial machines with capacity ratings up to 5 megawatts. Photo by Mark McDade, NREL 24472

\section{Ingersoll Rand}

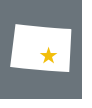

\section{Pueblo, Colorado}

Ingersoll Rand pledged to reduce its global energy intensity by $25 \%$ by 2019 . To achieve this, the company has implemented a three-tiered energy audit program that reduces energy use and operating costs at many of its largest manufacturing sites. As part of this effort, an Ingersoll Rand facility in Pueblo, which is the primary site for manufacturing energy-efficient commercial chillers, completed several energy management audits during 2009 and 2010. These audits identified more than 40 opportunities for energy-efficiency improvementsgenerating more than $\$ 400,000$ in annual energy savings. Ingersoll Rand has saved more than $\$ 4$ million in energy costs globally since the inception of its auditing efforts in $2005 .{ }^{15}$

\section{Projects to Watch}

EERE continually invests in energy efficiency and renewable energy technologies, and we anticipate several recent investments will spur jobs and save consumers money.

\section{Making Wave Power Efficient and Affordable}

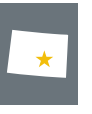

Colorado Springs, Colorado

EERE investment: $\$ 400 \mathrm{~K}$

Partnering with Colorado Springs' Atargis Energy, EERE is supporting efforts to design and test wave energy conversion devices that can survive significant storms and deliver cost-competitive electricity-two issues that face wave energy conversion devices under development. Atargis is currently testing its Cycloidal Wave Energy Converter design at the Texas A\&M Offshore Technology Research Center in College Station, Texas. The company hopes to demonstrate, on a kilowatt scale, the world's first fully submerged wave energy converter system that will be capable of achieving a $70 \%$ overall wave-to-electric power conversion efficiency and a levelized energy cost below $\$ 0.14$ per kilowatt hour.

\section{New Geothermal Exploration and Management Tools}

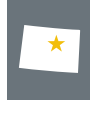

$$
\begin{aligned}
& \text { Golden, Colorado } \\
& \text { EERE investment: } \$ 1.6 \mathrm{M}
\end{aligned}
$$

To better isolate potential geothermal resources that lack surface manifestations, EERE has partnered with the

Colorado School of Mines to advance resource discovery. The University is developing a method to comprehensively target geothermal drilling by combining geophysical data sets to generate more complete images of the subsurface and fluid flow within geothermal systems. The Colorado School of Mines is also developing geochemical exploration tools that will enable the cost-effective discovery and management of geothermal resources specific to the Great Basin, a watershed that stretches across California, Nevada, Oregon, Idaho, Utah, and Wyoming.

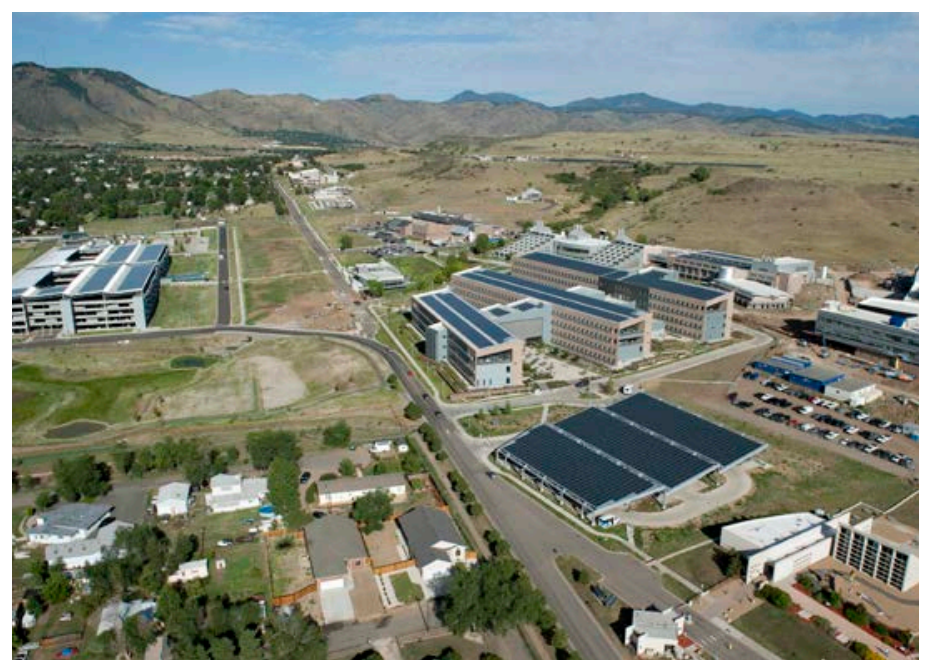

The National Renewable Energy Laboratory, located in Golden, Colorado, is EERE's primary national laboratory for renewable energy and energy efficiency research, development, demonstration, and commercialization activities. Photo by Dennis Schroeder, NREL 21780 


\section{Challenging a New Generation of Clean Energy Entrepreneurs}

\section{Boulder, Colorado}

EERE investment: $\$ 360 \mathrm{~K}$

Over a 3-year period, EERE's investment will support the University of Colorado-Boulder's (CU) Cleantech New Venture Challenge, an annual student business plan competition that develops partnerships among regional entrepreneurs and innovators at universities, national laboratories, and other organizations. The CU Cleantech New Venture Challenge is one of six DOE-funded regional business plan competitions under the U.S. DOE National Clean Energy Business Plan Competition, which was launched in 2012 to engage students in the acceleration of clean technology startups and innovation. ${ }^{16}$ The winner of the Cleantech New Venture Challenge receives the $\$ 100,000$ annual prize, and competes in the national competition for an additional $\$ 100 \mathrm{~K}$ grand prize; the top three teams are eligible to receive commercialization assistance from NREL, as well as entrance to its annual Industry Growth Forum in Denver.

\section{Deploying Clean Energy Solutions in Colorado Communities}

EERE invests in the deployment of energy efficiency and renewable energy projects in communities across Colorado. These investments catalyze economic development, create jobs, generate clean energy, and reduce utility bills. Many of these investments are a result of the American Recovery and Reinvestment Act (ARRA). Of more than $\$ 180$ million in ARRA funds allotted to the state of Colorado, more than $95 \%$ has been spent as of January 2013 through EERE's Energy Efficiency and Conservation Block Grant Program, State Energy Program, and Weatherization Assistance Program.

\section{Building Clean Energy Infrastructure}

With financial and technical support from EERE, energy officials at the state level and in 34 communities have selected and overseen completion of hundreds of projects that are delivering the benefits of clean energy to citizens throughout Colorado. EERE allocated approximately $\$ 100$ million in ARRA funds to support activities that

- Contributed to the increased energy efficiency of more than 30 million square feet of building space through retrofits

- Installed nearly 1,300 renewable energy systems, with a total capacity of more than 2,700 kilowatts in wind, solar, and hydropower energy systems
- Funded nearly 1,600 workshops to educate more than 58,000 people in how to perform energy audits and upgrades and contribute to the installation of renewable energy systems

- Installed more than 300 energy-efficient streetlights and nearly 4,100 energy-efficient traffic signals.

\section{Weatherizing Homes for Lower Income Families}

Colorado has spent more than $94 \%$ of the more than $\$ 80$ million in ARRA funds it received to weatherize homes. Colorado has weatherized and re-weatherized more than 20,200 homes since 2009, surpassing its weatherization goals under ARRA by $35 \%$. To date, this effort has resulted in total annual energy savings of more than 587 billion British thermal units and 54,000 metric tons ${ }^{17}$ of carbon pollution averted, which is the equivalent of taking more than 10,500 passenger vehicles off the road for a year. ${ }^{18}$ The projects have enabled income-eligible families to save hundreds of dollars per year on heating and cooling bills by improving their homes' energy efficiency, as well as the health and safety of home environments. ${ }^{19}$

\section{Deployment Project Examples in Colorado Communities}

\section{Ouray Reduces Energy Costs through Renewable Energy Installations}

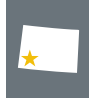

Ouray, Colorado

EERE investment: \$20K

The City of Ouray installed geothermal technology at the 'City Shop,' which is the City's maintenance garage for public works vehicles. The City Shop sits close to a hot water line, which flows at 153 degrees from an artesian spring to heat a municipal swimming pool. The City expects its new heat exchanger (a geothermal system) to supply $80 \%$ of the building's heating needs - a savings of about $\$ 5,000$ per year in natural gas expenditures, or $\$ 150,000$ over the expected 30 -year life of the project. In addition, the City will be able to collect valuable data to help determine the feasibility of similar projects.

\section{Weatherization Effort Creates Jobs for Veterans}

叹

Denver and Jefferson County, Colorado

EERE investment: $\$ 13.8 \mathrm{M}$

EnergyLogic Solutions, a veteran-owned organization and Colorado's leading provider of home energy efficiency training and software services, partnered with Veterans Green Jobs to hire both veterans and non-veterans to work in the state's weatherization program..$^{20}$ As a result, these trained and employed individuals will continue to serve their communities while learning the skills necessary to prosper in a green economy. ${ }^{21}$ 


\section{Student Energy Auditors Assist Colorado Springs in Reducing Energy Costs Through Renewable Energy Installations}

\author{
Colorado Springs, Colorado \\ EERE investment: \$3.6M
}

The City of Colorado Springs is reducing energy waste throughout the community through energy audits of city-owned buildings, municipal energy improvements, energy upgrades to streetlights, and the weatherization of low-income homes. Students from three universities in Colorado Springs - University of Colorado at Colorado Springs, Colorado College, and Pikes Peak Community College - conducted hands-on energy audits of several local businesses, which then received energy-efficiency upgrades. These facility upgrades reduced energy consumption and decreased utility costs for the participating small business owners.

\section{Energy Efficiency Upgrades Save Taxpayer Dollars}

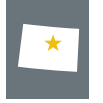

\author{
Jefferson County, Colorado \\ EERE investment: \$2.2M
}

Jefferson County sought energy-efficiency upgrades to municipal structures, including lighting upgrades and the implementation of energy policies in public buildings. The installation of compact fluorescents, as well as LED exit signs and occupancy sensors, will save the county approximately $\$ 54,000$ annually. By implementing energy policies in public buildings - such as automated "shut-down" of computers and pre-set thermostats - the county expects to save more than $\$ 60,000$ in the first year and reduce carbon dioxide emissions by 1224 metric tons per year. In total, these projects will help Jefferson County reduce carbon dioxide emissions by 2449 metric tons per year and will ultimately save taxpayers approximately $\$ 280,000$ per year in energy costs.
I"Sizing the Clean Economy: A National and Regional Green Jobs Assessment." The Brookings Institution and Battelle, July 2011. http://www.brookings.edu/research/reports/2011/07/13-cleaneconomy; http://www.brookings.edu/ /media/Series/Clean\%20Economy/08.PDF.

2“Colorado State Profile and Energy Estimates." U.S. Energy Information Administration, July 2012 http://www.eia.gov/state/state-energyprofiles.cfm?sid=CO.

"2011 Wind Technologies Market Report." EERE, August 2012. http://www1.eere.energy.gov/wind/ pdfs/2011_wind_technologies_market_report.pdf. Percentage on an average year basis.

4“2011 Wind Technologies Market Report." EERE, August 2012. http://www1.eere.energy.gov/wind/ pdfs/2011_wind_technologies_market_report.pdf.

5“2012 Renewable Energy Data Book.” EERE, 2011. http://www.nrel.gov/analysis/pdfs/51680.pdf. 6"Colorado State Profile and Energy Estimates." U.S. Energy Information Administration, July 2012. http://www.eia.gov/state/state-energy-profiles.cfm?sid=CO.

“Database of State Incentives for Renewables \& Efficiency." EERE, 2012. http://www.dsireusa.org/. 8“New Investment in Clean Energy Fell 11\% in 2012." Bloomberg New Energy Finance, January 2013. http://about.bnef.com/2013/01/14/new-investment-in-clean-energy-fell-11-in-2012-2/.

${ }^{9}$ This August 2011 competitive award builds on a prior Small Business Investment Research award.

10“How much electricity does an American home use?” FAQ, U.S. Energy Information Administration, December 2011. http://www.eia.gov/tools/faqs/faq.cfm?id=97\&t=3.

"'Boulder Canyon Hydroelectric Plant Modernization Project." City of Boulder, Colorado, October 2012. http://www.bouldercolorado.gov/index.php?option=com_content\&task=view\&id=12679\&lte mid= 5520

12“"Recharge Colorado." Recharge Colorado, 2012. http://rechargecolorado.org/index.php/ residential_resources/home_energy_savings_guides/appliances_and_electronics/

13 “Better Buildings Challenge Continues to Grow.” DOE, June 2012. http://energy.gov/articles/ better-buildings-challenge-continues-grow.

14“Energy Smart Colorado." Energy Smart Colorado, 2012. www.EnergySmartColorado.com; "Eagle County, Colorado." EERE, 2012. http://www1.eere.energy.gov/buildings/betterbuildings/ neighborhoods/eagle_county_profile.html; "Energy Smart Colorado." Eagle County, Colorado, 2012. http://vimeo.com/37343186.

15"Ingersoll Rand Discovers Hidden Savings with a Three-Tiered Energy Audit Model." EERE, 2010. http://www1.eere.energy.gov/manufacturing/tech_deployment/pdfs/ingersoll rand_success story. pdf; "Frequently Asked Questions." EERE, 2012. http://www1.eere.energy.gov/manufacturing/ tech_deployment/betterplants/faqs.html\#general1.

16"Startup America." The White House, 2011. http://www.whitehouse.gov/economy/business/ startup-america. The National Clean Energy Business Plan Competition is part of the Startup America Initiative to inspire and promote entrepreneurship.
17"Emission Facts: Average Annual Emissions and Fuel Consumption for Passenger Cars and Light Trucks." EPA, April 2000. http://www.epa.gov/otaq/consumer/f00013.pdf.

${ }^{18}$ Estimated with U.S. Environmental Protection Agency's Greenhouse Gas Equivalencies Calculator which can be found at http://www.epa.gov/cleanenergy/energy-resources/calculator.html.

19 "Residential Energy Consumption Survey." (2009). U.S. Energy Information Administration. http://www.eia.gov/consumption/residential/.

${ }^{20}$ The Veterans Green Jobs Weatherization Program in Denver and Jefferson County is the largest non-profit weatherization provider in Colorado and a subgrantee of the state's weatherization assistance program, which received EERE funds through ARRA. The program provides weatherization services to two areas of the state: Denver and Jefferson Counties and the San Luis Valley.

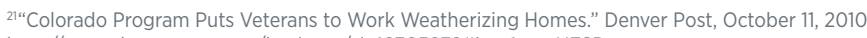
http://www.denverpost.com/business/ci_16305979\#ixzzlyoteUESP.

${ }^{22}$ "Retrospective Benefit-Cost Evaluation of U.S. DOE Vehicle Combustion Engine R\&D Investments: Impacts of a Cluster of Energy Technologies." DOE, May 2010. http://www1.eere.energy.gov/analysis/ pdfs/advanced_combustion_report.pdf.

${ }^{23}$ "Retrospective Benefit-Cost Evaluation of DOE Investment in Photovoltaic Energy Systems." DOE, August 2010. http://www1.eere.energy.gov/analysis/pdfs/solar_pv.pdf.

24“"Retrospective Benefit-Cost Evaluation of U.S. DOE Wind Energy R\&D Program,” DOE, June 2010 http://www1.eere.energy.gov/analysis/pdfs/wind_bc_report10-14-10.pdf.

${ }^{25}$ National Research Council. Energy Research at DOE: Was It Worth It? Energy Efficiency and Fossil Energy Research 1978 to 2000. Washington, DC: National Academies Press, 2001.

26“"DOE Hydrogen and Fuel Cells Program Record \#12020," DOE, September 27, 2012. http://hydrogen.energy.gov/pdfs/12020 fuel cell system cost 2012.pdf. Based on projections to high-volume manufacturing.

27"Retrospective Benefit -Cost Evaluation of DOE Investment in Photovoltaic Energy Systems." DOE, August 2010. http://www1.eere.energy.gov/analysis/pdfs/solar_pv.pdf.

${ }^{28}$ "Retrospective Benefit-Cost Evaluation of U.S. DOE Wind Energy R\&D Program," DOE, June 2010 http://www1.eere.energy.gov/analysis/pdfs/wind_bc_report10-14-10.pdf.

29“"Weatherization Assistance Program." EERE, May 2009. http://www1.eere.energy.gov/wip/pdfs/ wap_factsheet.pdf.

30“"Building Technologies Program: History and Impacts." EERE, 2013. http://www1.eere.energy.gov/ buildings/appliance_standards/history_and_impact.html.

31“"Energy Technology Solutions: Public-Private Partnerships Transforming Industry.” EERE, December 2010. http://www1.eere.energy.gov/manufacturing/pdfs/itp_successes.pdf.

32“Facilitating Cost-Effective Federal Energy Management.” EERE, December 2012 http://wwwl.eere.energy.gov/femp/pdfs/femp_fs.pdf. 


\section{A Proven Track Record}

\section{Snapshot of National Outcomes from EERE Investments}

EERE's Return on Investment for Clean Energy Technologies

- EERE's $\$ 931$ million investment in vehicles combustion engine R\&D from 1986 to 2007 achieved a net benefit of $\$ 69$ billion (2008 dollars) in fuel savings for users of heavy-duty diesel trucks. ${ }^{22}$

- EERE's \$3.7 billion investment in solar photovoltaic R\&D from 1975 to 2008 resulted in a net economic benefit of \$15 billion (2008 dollars) due to module efficiency and reliability improvements. ${ }^{23}$

- EERE's $\$ 1.7$ billion investment in wind energy R\&D from 1976 to 2008 resulted in a net economic benefit of \$8.7 billion (2008 dollars) due to wind turbine efficiency, energy capture, and reliability improvements. ${ }^{24}$

- A 2001 National Academy of Sciences analysis found that investments of \$1.6 billion in energy efficiency R\&D in the first two decades of DOE's existence from 1978 to 2000 realized a net economic benefit of approximately $\$ 30$ billion (1999 dollars). ${ }^{25}$

Sustainable Transportation

- EERE research has helped reduce production costs of automotive lithium-ion batteries by more than $50 \%$ since 2008 and is on track to reach its goal of enabling cost-competitive market entry of plug-in hybrid electric vehicles within the next 10 years.

- EERE's activities to achieve cost-competitiveness for biofuels have resulted in the recent achievement of reaching a modeled cellulosic ethanol production cost of $\$ 2.15$ per gallon of ethanol (or \$3.27 per gallon of gasoline equivalent).

- EERE's efforts have reduced the projected costs of automotive fuel cells (assuming high-volume manufacturing) by more than $35 \%$ since 2008 and $80 \%$ since 2002-doubling the durability of fuel cells from 950 hours of demonstrated operation in 2006 to more than 2,500 hours of operation on the road. ${ }^{26}$

\section{Renewable Electricity Generation}

- Without EERE involvement, the average solar photovoltaic (PV) module production cost per watt would have been $\$ 5.27$ in 2008, rather than \$1.92. EERE has accelerated solar industry progress by an estimated 12 years. ${ }^{27}$

- Without EERE involvement, cumulative wind power deployment through 2008 would have been less than a third of actual 2008 levels. EERE has accelerated the overall progress of the wind industry by an estimated 6 years. ${ }^{28}$

Energy-Saving Homes, Buildings, and Manufacturing

- More than 6,200,000 homes have been weatherized with EERE funding provided to states or leveraged from other sources with EERE support since 1976-creating an average energy savings of \$350 or more per year and avoiding \$1.6 billion in energy costs during winter 2005 alone for all households weatherized. ${ }^{29}$

- Due to EERE appliance standards implemented through 2012, a typical household today already saves about \$180 per year off its utility bills. Households can expect to save more than $\$ 300$ per year by 2030 , as they replace their existing appliances with newer models that use less energy - a cumulative savings to consumers of more than $\$ 900$ billion by 2020 , and more than $\$ 1.6$ trillion through 2030 . The cumulative energy savings of these standards phased in through 2012 will be about 70 quadrillion British thermal units (quads) of energy through 2020, and will amount to 120 quads through 2030. (The United States consumes a total of about 100 quads of energy per year.) ${ }^{30}$

- EERE and its partners in the manufacturing sector have successfully launched 220 new, energy-efficient technologies, received 78 R\&D 100 Awards, and delivered technical assistance to more than 33,000 industrial plants. ${ }^{31}$

- Since 2005, EERE has facilitated $\$ 3.1$ billion of efficiency investments in federal government facilities from performance-based contracts, which will result in energy cost savings of approximately $\$ 8.5$ billion over the life of the energy-saving measures. The savings on utility bills and operation and maintenance created through the facility upgrades will be used to pay for the project over the term of the contract, and the agencies will continue to save money and energy after the contract term has ended. ${ }^{32}$

The Office of Energy Efficiency and Renewable Energy is at the center of creating the clean energy economy today. We lead U.S. Department of Energy efforts to develop and deliver market-driven solutions for renewable electricity generation; sustainable transportation; and energy-saving homes, buildings, and manufacturing. To learn more about the activities of the Office of Energy Efficiency and Renewable Energy, visit eere.energy.gov. If you have questions or comments about the information in this document, please contact us at EE.Communications@ee.doe.gov.

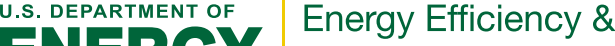 ENERGY Renewable Energy} including $10 \%$ post consumer waste. 